\title{
Ethnicity and National Integration in Nigeria: Towards the Use of Indigenous Language Option for Information Dissemination at the Grassroots
}

\author{
Aghaegbuna Haroldson Uwaezuoke \\ http://dx.doi./org/10.4314/ujah.v19i2.3
}

\begin{abstract}
The linguistic complexity of Nigeria and the affinity of the indigenous languages to the diverse ethnic nationalities have made the issue of national integration become very worrisome and seem unattainable in the country. The different ethnic nationalities have continued to live in mutual distrust of one another. Apart from the National Policy on Education, which recognises Igbo, Hausa and Yoruba as the majority languages and also encourages every child to learn one of them in addition to the child's mother tongue, government is yet to boldly come up with an official national language policy for Nigeria. In this paper, the use of indigenous languages to disseminate information to Nigerians, in addition to English, which is the country's official language, is considered another option towards solving the country's problem of national integration. The paper anchors on the Relevance theory. Earlier views of scholars are reviewed from where this paper veered. It is concluded with a suggestion that government policies and programmes should be translated into the indigenous languages and widely circulated for better awareness, understanding and participation/contribution of Nigerians to national issues. This would engender effective grassroots mobilisation for national integration and national development.
\end{abstract}

Key words: ethnicity, indigenous language and national integration. 


\section{Introduction}

Language is a means of communication between individuals and different groups of individuals in a given society. It is a socialising tool capable of breaking barriers of inter-ethnic communication and mistrust (Ezeani, 2015, in Nkamigbo and Asadu, 2015:181). Through language, information is passed across to so many individuals and awareness created. That is why Knowles in Hickey (1998:103) avers that the purpose of a particular act of communication is possibly to transmit to somebody a message which results in the increment of the recipient's knowledge, while to Umanah in Akeredolu-Ale (1993: 163), it is the mobilization of the rural populace for rural development. What these views suggest is that through language, people become more knowledgeable and better positioned to make meaningful contributions. It goes further to underscore the importance of making a right choice of language for communication as that will determine how effective communication would be.

The problem posed by the multilingual nature of Nigeria made English to be adopted as the nation's official language. Through this policy, government businesses are conducted in the English language. English is also used in teaching in schools and for passing information to Nigerians, majority of who reside in the rural area and who are not literate in the use of the English language. Therefore, rather than solving the problem, the policy has sort of worsened the situation. The major problem identified by this paper is that Nigerian Government tends to ignore the importance of harnessing the indigenous languages of the diverse ethnic nationalities as a tool for achieving national integration. They rather promote the English language and other European languages which are alien to Nigerians. Most often, it becomes 
problematic communicating to the rural populace because more than half of them are not literate in the use of English, the official language. Through this means, majority of Nigerians have become alienated from government activities, a situation which has drastically reduced the level of awareness of the grassroots' people and hindered their effective mobilisation for national integration and national development. In the opinion of Momoh (1993) cited in Akeredolu-Ale(1993:16), this kind of situation would make the rural people to remain observers rather than being active participants in matters affecting them. It, therefore, calls for the need to have a rethink and to fashion out a better option that can engender effective mobilisation of the majority of Nigerians at the grassroots.

In this paper, it is argued that the use of the indigenous language(s) in Nigeria in disseminating vital government information to the rural populace would engender effective grassroots mobilisation as well as enhance national integration and national development. This is not far from the views of Odunlami (1999), Ezeikeojiaku (2007) cited in Ugochukwu and Ogwudile (2017), Djite (2008) and Kateregga (2011).Odunlami (1999), for instance, suggests that more programmes should be broadcast on both the radio and television in local languages, while the print media should endeavour to produce and circulate more vernacular newspapers. Ezeikeojiaku (2007) asserts that people think more productively in their indigenous language. Uwaezuoke (2015) had also earlier recommended the dissemination of information at the grassroots through translating government policies and programmes and other vital documents from the official language or any other foreign language(s) into the indigenous language(s) of the target audience as the surest way of creating awareness to the rural populace. This suggestion is in line with House's (2009:3) 
assertion that "with translation, however, communicative events are reduplicated for people originally prevented from participating in, or appreciating the original events". Some concepts need to be expatiated on. The next section, therefore, presents the conceptual review.

\section{Theoretical Framework}

The thrust of Relevance theory is on the communicative use of translation. It provides concepts that can help to better understand the nature of translation and some of the problems it typically involves (Gutt, 1998, in Hickey,1998:41). It has some basic elements captured by Gutt (1988) in Hickey (1998:41-45), which are:

1. Inferential Nature of Communication - Under this concept, communication is considered as involving inference. This is in addition to its requirement of encoding, transfer and decoding processes. It emphasizes the importance of context in deciphering the intended meaning of an utterance. It argues that the same utterance can convey opposite meanings such that the meaning of an utterance does not only depend on its semantic content but also on the context of interpretation or on the contextual information with which it is inferentially combined. The application of wrong context can lead to a complete failure of communication. Therefore, the success of communication can depend very much on whether the audience uses the speaker-intended context.

2. Optimal Relevance - This concept emphasizes the optimal relevance of a message of communication to the target audience. It believes that whenever a person sets out to communicate, he or she automatically communicates the 
presumption that what he or she says would be optimally relevant to the audience. An utterance is said to be optimally relevant when (a.) it enables the audience to find out without unnecessary effort the meaning intended by the communicator, and (b.) when that intended meaning provides adequate benefit to the audience. The search for optimal relevance guides the hearer not only to the speaker-intended context but also to the speaker-intended interpretation (Gutt, 1998 in Hickey, 1998: 44). With the use of indigenous language option for communication to the rural populace, they would understand the message being passed across to them as well as its optimal relevance.

3. Interpretive and Descriptive Use of Language - Relevance theory claims that the descriptive and interpretive uses of language are the two psychological distinct modes of using language. When a language utterance is intended to be taken as true of a state of affairs in some possible world, it is said to be used descriptively, but when an utterance is intended to represent what someone said or thought, it is said to be used interpretively.

4. Interpretive Resemblance and Faithfulness - This concept says that there is a relationship of interpretive resemblance between the original utterance and that used to represent it. When the translator in constrained by the principle of relevance, he or she will aim at resemblance in those aspects which to him will satisfy the expectation of optimal relevance. At this point, the utterance of the speaker comes with a claim of faithfulness. As put by Wilson and Sperber (1988:137), 'The speaker guarantees that her utterance is a faithful enough representation of the original, that is, resembles it closely enough in relevant respect. The fidelity of the message transferred to the 
indigenous languages to the message in the original text is ensured. This is because the two messages would have true resemblance and the version in the indigenous languages would be easily appreciated by the target audience since familiar codes are used.

Since the essence of translating government policies and programmes is for communicative purpose, the Relevance theory would require the translator to consider these basic elements for the translation to be effective. The issue of equivalence is considered very important as the message in the target language text must as a matter of necessity relate to the same message in the source language text in order to create the same effect. House (2009:29) succinctly captures what equivalence entails, thus:

Equivalence does not mean that two things are identical but that they have certain things in common and function in similar ways. This means that a particular source text will have many different translation texts that can be called 'equivalent' to the source text in different ways, depending on how similarity of message or function is interpreted; this will have to take into account varying pragmatic factors, the difference between the two systems involved, and so on.

Equivalence refers to something standing in for another thing. It focuses mainly on meaning rather than form. In other words, words used in both the source language and the target language may have different structures but they carry the same message. Their styles may also be different but they contain the same meaning e.g. 1(a) English: There is no smoke without fire.

Igbo: Awọ adịghị agba ọsọ ehihie n’efu. 
(b) English: Too many cooks spoil the broth.

Igbo: Adịghị iri etinye nnu n'ofe.

(Adapted from Uwaezuoke, 2015)

The structures of the expressions in (1) differ, but they convey the same meanings. The Igbo versions are, therefore, the equivalents of the English versions. This is the thrust of this paper, that is, that equivalents of government's policies and programmes originally in the nation's official language should be provided in the indigenous languages for better understanding, appreciation and input of the target audience. Some studies have been done in the past, which bother on the importance of indigenous languages for effective communication. Some of these past studies are reviewed in the next section.

\section{Indigenous Languages and National Integration}

Ezeuko and Mbagwu (2009) conducted a study on five selected villages in the south-eastern part of Nigeria to determine the level of literacy of the Nigerian populace. They used a test of listening and interpreting, reading and interpretation, and writing. The results reveal a low level of literacy in English in the selected villages. Ezeuko and Mbagwu (2009) aver that effective communication is the type that involves senders and receivers, whereby the senders have foreknowledge of the message and articulate it through language that captures the core and nuances of the message, while the receivers would perceive the message and appropriately decode it as would manifest in their corresponding and appropriate response to the message. They consider ineffective communication to be responsible for most unsatisfactory situations that dominate all the facets of the country's life, such as: retarded 
economic development, poor education, restiveness, religious conflicts, poor health and high mortality rate.

In order to minimise ineffective communication, the scholars recommend the development of indigenous languages, training of teachers to use the mother tongue for instruction, making the Nigerian Pidgin official, identifying the communicative roles English cannot play in the different speech communities in the country. This present paper agrees with Ezeuko and Mbagwu. Its point of departure lies with it canvassing for the translation of government policies and programmes as an option that can engender the desired mobilization of diverse ethnic nationalities for national integration.

Ugochukwu and Ogwudile (2017) contend that communication involves passing and receiving information. They point out that effective communication can only be achieved through language that strongly appeals and influences the people to implement decisions. Based on the potentials of indigenous languages in enhancing cognitive understanding and removing pedagogical barriers in learning as noted by the Native American Language Research, the University of Bradford Research, the Ife Six Year Primary Project and the Swahili Research, they advocate the use of indigenous language in communicating the message of change in an organisation. This paper relates to Ugochukwu and Ogwudile because they both promote the use of indigenous languages for communication, but while it emphasises translation of government policies and programmes into the indigenous languages for effective grassroots mobilisation, Ugochukwu and Ogwudile lay emphasis on the use of indigenous languages for communicating message of change in an organisation.

Ezeani (2015) is a paper on Language and culture: Pragmatic instruments for national cohesion. He avers that the 
problem of national integration originated from the forceful unification of the diverse ethnic nationalities, while resources from one part (South) were deployed into developing the other part (the North) without considering the fate of the South or the unity of the entire nation. It is inferred from this opinion that the original plan of the British was never to develop Nigeria but to sow a perpetual seed of discord among the ethnic nationalities bundled as one nation. Not surprising, therefore, that Ezeani disclosed that since independence, Nigeria had moved from one crisis to another and remained a smouldering edifice without semblance of unity, stability or committed patriotism among the federating ethnic nationalities.

He argues that the solution to the plaguing issue of disunity and mistrust in the nation is for a provision in the Nigerian Constitution a clause that would encourage the citizens to speak, at least, one indigenous language other than their mother tongue. This suggestion is in line with Kalu's (1987:137)earlier opinion. Ezeani also suggests that the leaders should take the entire nation as their constituency and let transparency, equity, justice and due process be their grund norm. The first suggestion by Ezeani is considered to have been taken care of by the National Policy on Education (NPE) (see Okediadi, 2009) unless what he means is for it to be recaptured within a Nigerian Language Policy (NPL). Whatever is the case, without serious efforts, the story would remain the same. It is this serious effort on the part of Government that this paper battles with. The second suggestion is considered germane since it would engender mutual trust among Nigerians. As noted by Ezeani, a virile, united, peaceful and progressive Nigeria requires an agreement by Nigerians to understand one another. Put in another way, a virile, peaceful and progressive Nigeria requires a perfect understanding and appreciation of government policies and 
programmes by Nigerians. This can only be possible when familiar linguistic codes (the indigenous languages) are used to pass information to diverse ethnic nationalities (See Djite, 2008, in Kateregga, 2011).

The harnessing of the motley cultures and languages Nigeria's heterogeneity endows the country with would lead to national integration (Ezeani, 2015). Agreeing with this view, this paper adds that Government should encourage a simultaneous development of the indigenous languages of the diverse ethnic nationalities and consider translating Government's policies and programmes into these languages for the diverse ethnic nationalities' better understanding, appreciation and input. Translation of these policies and programmes into the indigenous languages is one thing and their circulation to the masses another. In the next section, the means of circulating them are presented.

\section{Means of Circulating the Translated Versions}

Earlier investigation by Uwaezuoke (2015) has shown that apart from the problem of not always translating government policies and programmes into the indigenous language(s) for effective communication to the people at the grassroots, there is the problem of transmitting those policies and programmes of government that are translated into the indigenous language(s) to the people at the grassroots. In order to ameliorate the problem, Uwaezuoke (2015) in Nkamigbo and Asadu (2015:242-243) proffers useful suggestions on how to reach the grassroots with the translated texts. For emphasis, the recommendations are represented below:

1. Organisation of Public Enlightenment Campaigns: Government should organize public enlightenment campaigns in the rural areas 
as the need arises and use the indigenous languages to sensitize the masses on the policies and programmes that should be of interest to them. Since there are several Federal Information Centres and Sub-Centres across the country as well as the National Orientation Agency (NOA), with officers in all the states and local government areas of the federation, the Information Unit of each of the local governments should liaise with them to organize public enlightenment campaigns in their locality. While doing this, they should endeavour to go with the translated versions of the policies and programmes.

2. The Use of the Media: Government should make use of the media houses, especially the electronic media, in disseminating vital information to the people in the rural area through the indigenous language sessions. This view had earlier been canvassed by Odunlami (1999: 105) who adds that the print media should endeavour to produce and circulate more vernacular newspapers. Umanah (1993) in Akeredolu-Ale (1993: 168), however, opines that community newspapers are ill-equipped in nature and operational modality to be easily adaptable as an instrument of rural social mobilization and rural social transformation.

3. The Use of Churches: Churches should be used by government for the dissemination of vital information as well as distribution of translated versions of the government policies and programmes.

4. The Use of Councillors: Councillors represent the interest of the people of their wards and, therefore, are their watch-dogs. As such, they should be used to transmit to the grassroots those translated policies and programmes of government that are for the benefit of the people. Moreover, Councillors are expected to have Ward Offices. Government should encourage the Councillors to open these Ward Offices, which will equally serve as contact 
places, where Councillors would from time to time invite the people of their Wards for briefing and periodic rendering of accounts of their stewardship.

5. Establishment of ICT Centres: Government should establish ICT centres in all the communities for easy access by the people in the rural area. These ICT centres could be located at the Civic Centres of every community and manned by an officer of the local government who will also aid people to access whatever information they need. Both the original and the translated versions of the government policies and programmes should be put in the net for people to access.

6. The Use of Indigenous Languages to Teach in Schools: Government should encourage the use of indigenous languages to teach the pupils/ students in schools, especially for the science and technology related courses.

7. Engagement of Trained Translators: Government should endeavour to get the services of trained officers in the art of translation from official language to indigenous languages.

8. Encouragement of Adult Education and Literacy Campaign: Government should be more serious with its adult education and literacy campaign programmes, especially in the rural area. This will take care of those individuals who understand the English language but cannot read materials written in English.

\section{Summary and Conclusion}

This paper presented an argument in support of the use of indigenous languages to disseminate information to the diverse ethnic nationalities in Nigeria, in addition to English, the country's official language. This was premised on the fact that Nigeria has a complex linguistic system where each language has an affinity 
with an ethnic nationality and the different ethnic nationalities have continually lived in mutual distrust of one another.

The paper discussed some key concept such as ethnicity, indigenous language and national integration. It considers ethnicity as referring to an ethnic group with common identity, the same social setting with the same or minor differing cultural traits; indigenous language is viewed as a language of an ethnic group which has its cultural nuances and of which the members of the ethnic nationality become familiar with as they grow-up; while national integration refers to a situation where members of the diverse ethnic nationalities are united in presenting a common front for the well-being of the entire nation.

Based on the Relevance theory which presents Inferential Nature of Communication, Optimal Relevance, Interpretive and Descriptive Use of Language, and Interpretive Resemblance and Faithfulness as the basic elements towards effectiveness of communication, this paper has considers the use of indigenous languages for information dissemination necessary. It reviewed past works that also support the promotion of the indigenous languages, but noted that the difference between them (the present paper and the past works) stems from the fact that none of them emphasises the translation of government policies and programmes as a way forward for promoting national integration in Nigeria.

It is the belief of this paper that the use of the indigenous languages of Nigeria in disseminating vital government information to the diverse ethnic nationalities would engender effective grassroots mobilisation for national integration and national development. 


\section{Aghaegbuna Haroldson Uwaezuoke \\ Department of Linguistics \\ Nnamdi Azikiwe University, Awka \\ uwaezuokeha@gmail.com \\ ha.uwaezuoke@unizik.edu.ng}

\section{References}

Akamadu, Chuks. 2013. "Laughable quest for nationhood". The Guardian (Nigeria) Newspaper. Monday September 2. p 65.

Akande, G. B. 2008. Straight for English as a medium of education in Nigeria: Towards enhancing quality and national development. Awka Journal of Linguistics and Languages. 4. 60-66.

Akata, Sordum Owen. 2013. Towards the era of using English as the only language for communication in Nigeria. Journal of the Linguistic Association of Nigeria. 16. $1 \& 2.43-61$.

Bakari, Salihu. 2017. National integration in humanities and development: The way forward. Unizik Journal of Arts and Humanities. 18i2. $358-374$.

Bamgbose, A. 2001. Language policy in Nigeria: Challenges, opportunities and constraints. Keynote Address Delivered at the First Nigeria Millennium Sociolinguistics Conference. University of Lagos, $16^{\text {th }}-18^{\text {th }}$ August, 2001.

Bertrand, J. 2004. Nationalism and ethnic conflict in Indonesia. Cambridge: Cambridge University Press.

Brubaker, R., M. Loveman and P. Stamatov. 2004. "Ethnicity and cognition". Theory and Society. Vol. 33. 31 - 64.

Burgess, M. Elaine. 1978. "The resurgence of ethnicity: Myth or reality?" In Ethnic and Racial Studies. 1. 270. 
Djite, P.G. 2008. The sociolinguistics of development in Africa. Clevedon: Multilingual Matters Ltd.

Ezeani, Emmanuel O. 2015. Language and culture: Pragmatic instrument for national cohesion. In Linda C. Nkamigbo and Felicia O. Asadu. Eds. Current Issues in Linguistics, Language and Culture Studies: A Festschrift in Honour of Professor Cecilia Amaoge Eme @ 50. Pp.178-187. Nkpor: Brystevand Publishers.

Ezeikeojiaku, P. A. 2007. Indigenous languages for science and technology. In B. N. Anasiudu et al. Eds. Language and Literature in Developing Countries. Onitsha: African-First Publishers Ltd.

Ezeuko, Romanus O. and Davidson U. Mbagwu. 2009. Ineffective communication in Nigeria: A problem associated with low level of literacy. UJAH: Unizik Journal of Arts and Humanities. 10. 2. 145 - 152.

Gutt, Ernst-August. 1998. Pragmatic aspect of translation: Some relevance - theory observations. In Leo Hickey. ed. The Pragmatics of Translation. pp. 41 - 53. Great Britain: Cromwell Press Limited.

Horowitz, D. L. 1985. Ethnic groups in conflict. Berkeley and Los Angeles: University of California Press.

House, Juliane. 2009. Translation. Oxford: Oxford University Press.

Irukwe, J. O. 1996. Nigeria: The case for a better society. Enugu: Fourth Dimension Publishing Company Ltd.

Kalu, Viktor Eke. 1987. The Nigerian condition - Arthur Nwankwo's viewpoints and blueprints. Enugu: Fourth Dimension Publishing Company Ltd.

Kateregga, Abubakar. 2011. The human resources paradigm as a tool for sustainable development in Africa: Assessing the 
indigenous language factor. Journal of the Linguistic Association of Nigeria. 14. 2. 297 - 309.

Knowles, Frank. 1998. 'New' versus 'Old'. In Leo Hickey. ed. The Pragmatics of Translation. pp. 103 - 113. Great Britain: Cromwell Press Limited.

Manor, James. 1996. "Ethnicity and politics in India". International Affairs (Royal Institute of International Affairs 1944-). Vol. 72, No 3. pp. 459 - 475.

Mbalisi, Chinedu N. 2017. Challenge of ethnicity, politics by identity and prebendalism to security and social stability in Nigeria, 1999 to 2015.Unizik Journal of Arts and Humanities. Vol. 18. 3. $70-97$.

Momoh, Tony. 1993. The role of the Mass Media in the promotion of integrated rural development. In Akeredolu-Ale. ed. Mass Media and Rural Development in Nigeria. pp. 16 -18. Ibadan: Spectrum Books Limited.

Nnoli, Okwudiba. 1980. Ethnic politics in Nigeria. Enugu: Fourth Dimension Publishing Company Ltd.

Obi, Nonyelum M. 2017. Literature in indigenous language: Its relevance to human development. Unizik Journal of Arts and Humanities. 18i2. 297 - 309.

Odunlami, I. S. 1999. Media in Nigeria's security and development vision. Ibadan: Spectrum Books Limited.

Okediadi, Nkechinyere Anthonia. 2009. Status and use of an indigenous language: The Igbo language dimensions. Unizik Journal of Arts and Humanities.10. 1. 140 - 159.

Onuko, Theodora. 2011. Multilingual education for nation building: The case for French language. Unizik Journal of Arts and Humanities. 12. 1. 90 - 101.

Osaghae, E. E. 1995. Structural adjustment and ethnicity in Nigeria. Uppsala: Nordic African Institute. 
Ugochukwu, Chinweude N. and Christian E. C. Ogwudile. 2017. The role of indigenous languages in successful change management: The Igbo language example. The Creative Artist. 13. 2. 488 - 500.

Ukiwe, Ukoha. 2005. On the study of ethnicity in Nigeria. CRISE: Centre for Research on Inequality, Human Society and Ethnicity. Working Paper No. 2. Oxford: CRISE.

Umanah, A. 1993.The community newspaper as an instrument of rural development. In Akeredolu-Ale.ed. Mass Media and Rural Development in Nigeria. pp.163 - 171. Ibadan: Spectrum Books Limited.

Uwaezuoke, Haroldson Aghaegbuna. 2015. An experimental survey of the impact of translation to information dissemination at the grassroots. In Linda C. Nkamigbo and Felicia O. Asadu. Eds. Current Issues in Linguistics, Language and Culture Studies:A Festschrift in Honour of Professor Cecilia Amaoge Eme @ 50. Pp. 235 - 244. Nkpor: Brystevand Publishers.

Varshney, Ashutosh. 2009. Ethnicity and ethnic conflict. In Carles Boix and Susan C. Stokes.Eds. The Oxford Handbook of Comparative Politics. Pp. 274 - 294.Oxford: Oxford University Press. Published online in September, 2009.

Ashutoshvarshney.net $>$ files_mf $>$ vrshn... (Assessed on 18/5/18).

Wan, Enoch and Mark Vanderwerf. 2009. A review of the literature of ethnicity, national identity and related missiological studies. www.GlobalMissiology.org. (Assessed on 17/5/18).

Wilson, D. and D. Sperber. 1988. Representation and relevance. In R. M. Kempson. ed. Mental Representations: The Interface between Language and Reality, pp. 133 - 153. Cambridge: Cambridge University Press. 
Sperber, D. and D. Wilson. 1986. Relevance: Communication and Cognition. Oxford: Blackwell.

Sperber, D. and D. Wilson. 1995. Relevance: Communication and Cognition, $2^{\text {nd }}$ Edition. Oxford: Blackwell. 